\title{
La belleza que más agrada al Amor (1)
}

The beauty which is the most pleasing to Love

Jorge Iván Ortiz Tangarife

Ingeniero administrador

Universidad Nacional de Colombia.

jorgeortiz8@gmail.com

Artículo recibido el 15 de octubre del 2016

Aprobado el 31 de octubre del 2016

\section{Resumen}

Según el texto Sobre el amor. Comentarios al banquete de Platón escrito por el filósofo humanista Marsilio Ficino en el siglo XV, la belleza que más agrada al Amor es la que proviene del alma y no del cuerpo. Es causada por Dios y regresará a Él cuando el alma también lo haga. De esta manera, esta belleza es inmortal como Dios mismo.

Palabras claves: Belleza, Amor, Dios, Alma, Cuerpo.

\begin{abstract}
According to the text Commentary on Plato's Symposium on Love written by the humanist philosopher Marsilio Ficino in the fifteenth century, the beauty more pleasing to Love is the one that comes from the soul and not the body. It is caused by God and it will return to Him when the soul also does. Thus, this beauty is immortal as God himself.
\end{abstract}

Key words: Beauty. Love, God, Soul, Body. 
El texto de Marsilio Ficino es una apología al amor, entendido como el deseo de belleza, la cual es causada por Dios. El autor revive el banquete de Platón, de modo que él y un puñado de amigos suyos se reúnen para comentar cada uno de los discursos que, sobre el amor, trataron los personajes del filósofo griego en su célebre texto El Banquete. Es imposible, siguiendo la obra de Ficino, hablar de forma separada sobre Dios, el amor o la belleza, como si de una trinidad indisoluble se tratase. Sin embargo, se hará cierto énfasis: ¿cuál es aquella belleza que más agrada al Amor?

Según Ficino "el Amor considera el goce de la belleza como su fin” (p.24). Pero no se refiere a la belleza corporal, la que proviene de las formas, la que puede percibirse con alguno de los sentidos. Hace alusión, en realidad, a una belleza superior, incorpórea, más cercana a Dios por no apuntar a materia alguna. Los amantes que fundamentan su amor en la belleza corpórea y en la concupiscencia, están condenados a un amor efímero. El deseo carnal es fugaz comparado con la eternidad del amor verdadero. El primero puede saciarse, el segundo es insaciable. La lascivia no conduce a la belleza que el amor espera como fin, por el contrario, "la lujuria atrae a los hombres hacia la intemperancia (...); por eso parece que atrae a los hombres hacia la deformidad, o sea a la fealdad” (p.25). La belleza que más agrada al Amor es la que procede del alma, la que puede apreciarse a través de la mente. El amor no busca cuerpos bellos, que como formas, mutan con el tiempo; sino almas bellas, que permanecen, que son eternas y simples como Dios mismo. "La hermosura incorpórea es la que gusta; y lo que gusta es grato; y lo que es grato es bello" (p.80).

Los amantes que dicen amarse pero que no ven más allá de la forma, no alcanzarán jamás el amor. Para Platón, las formas del mundo no son más que sombras de las formas verdaderas, de las ideas, que reposan en el lugar mismo del que descienden las almas. Por lo tanto, este mal llamado amor, es un amor entre sombras, un amor de tinieblas que no es bañado por el rayo de luz divino. En contraposición, los amantes que se enamoran del alma, más allá de todo sentido y de toda pasión, son aquellos que descubren el amor y, por ende, están más cerca de Dios, no en la forma, por ser sus cuerpos parte del mundo, sino en la esencia, en las almas, que inexorablemente regresarán a Él. Y al descubrir el amor, estos amantes tienen el privilegio de gozar de la belleza, que es el fin ulterior del amor. “¿Qué buscan los amantes cuando en forma recíproca se aman? Buscan la hermosura; el Amor es deseo de gozar de la hermosura, o sea de la belleza" (p.48).

Ahora, este amor que goza de la belleza, es inmortal. La eternidad se hace corta para el amor que trasciende lo mundano. "El Amor es inmortal porque la figura que se ama una vez, se sigue amando siempre" (p.131). Y aquí la palabra figura no hace mención a la forma de los cuerpos, la cual es mortal, sino a la esencia del alma. Cuando un amante se enamora de un alma, confinada en un cuerpo, siempre la amará, a pesar de que otros cuerpos, recipientes de otras almas, se crucen en su camino. De aquí se desprende, y Ficino hace distinción, entre amor unívoco y amor recíproco. En el primero, el amante deja de vivir en él mismo por amar al amado, pero al 
ser despreciado, tampoco vive en el amado, por lo que entonces está muerto. Es un alma no correspondida que no puede alcanzar la belleza. En el segundo, en cambio, las dos almas se corresponden, y fundidas en el amor, logran el fin último. Este amor recíproco, además de conseguir lo anterior, también tiene un propósito en el mundo: "el Amor es apetito de engendrar en el sujeto bello para conservar vida perpetua en las cosas mortales" (p.134). Con el amor recíproco se da perpetuidad en lo mortal y eternidad en lo incorpóreo.

La belleza que más agrada al Amor es, entonces, aquella que no se desprende de la forma sino del alma. Es aquella que es causada por Dios y que, por lo tanto, retornará a Él cuando las almas incorpóreas dejen el cuerpo del mundo. Y al ser el amor inmortal, por amar siempre la misma figura, la belleza, que se desprende de Dios, también debe ser eterna.

\section{Referencias}

Ficino, Marsilio. (1994). Sobre el amor. Comentarios al banquete de Platón. Ciudad de México: Universidad Nacional Autónoma de México.

(1). Citar este artículo como: Ortiz, J. (2016). “La belleza que más agrada al Amor”. En: Revista La Tercera Orilla (17). Bucaramanga: Universidad Autónoma de Bucaramanga. 